\title{
TRAVELER'S IDLE TIME AND THE VALUE CHAIN AT AIRPORTS
}

\section{Caglar UCLER*}

Ozyegin University, School of Aviation, Istanbul, Turkey, caglar.ucler@ozyegin.edu.tr

\section{Luis MARTIN-DOMINGO}

Ozyegin University, School of Aviation, Istanbul, Turkey, luis.martin@ozyegin.edu.tr

Received: $20^{\text {th }}$ April 2015, Accepted: $23^{\text {nd }}$ July 2015

\begin{abstract}
There is a high growth in the air traffic supported by the global trade and tourism and due to airport congestion travelers are spending more time at airports, which are competing to attract airlines with lower aeronautical costs reducing their profitability. The growing transit time spent at airports together with the waiting time in front of check-in, passport, security control or baggage claim is an idle time of the air traveler, which is not generating any value. The perception of waiting is also mostly negative, that the associated airports are disliked, leading to loss of revenue in commercial offerings. Another problem is that due to the high variety in the customer profile, the shops at the airports need to carry a high inventory over a wide spectrum of items required, which is not creating any value as well. Thus in order to deliver a sustainable value chain at the airport, an innovative customer focused integrated approach is proposed herewith, based on a smart phone platform called Gate $\varnothing$, facilitating the idle times of the air traveler. This strategic approach is evaluated successfully within a value chain analysis showing up its potential across the value chain stakeholders.
\end{abstract}

Keywords: Airport, Air Travel, Innovation, Mobile Application, Supply Chain, Value Chain Analysis.

\section{HAVA YOLCULARININ BOŞ ZAMANLARI VE HAVAALANINDAKİ DEĞER ZINCİRI}

\section{$\ddot{O Z E T}$}

Global ticaret ve turizm güdümünde artan hava trafiğinin sebep olduğu yoğunluk, hava yolcularının havaalanlarında giderek daha çok zaman geçirmesine sebep olmaktadır. Havaalanları ise rekabetçi olup, havayolu şirketlerini kazanabilmek için, havacılık gelirlerini giderek düşürmek zorunda kalmaktadırlar. Bununla beraber transit yolculuklar, check-in, pasaport ve güvenlik kontrolü ile bagaj için olan bekleme süreleri düşünüldüğ̈̈nde, hava yolcularının değer yaratmayan boş zamanları göze çarpmaktadır. Üstelik bu sebeple ortaya çıkan memnuniyetsizlik, ilgili havaalanlarının sevilmemesine ve buralarda elde edilen diğer ticari gelirlerin de düşmesine sebep olmaktadır. Ayrıca yolcuların değişken profili havaalanlarındaki ticari işletmeler için yoğun bir envanter maliyeti de oluşturmaktadır. Bu sebeplerden ötürü, havaalanlarına sürdürülebilir bir değer zinciri sağlayabilmek amacı ile, akıllı telefon platformları ile çalışan, Gate Ø adında yenilikçi ve entegre bir sistem önerilmiştir. Akabinde bu stratejik yaklaşımın sunduğu potansiyel, değer zinciri analizi ile incelenerek, başarılı bir şekilde gösterilmiştir.

Anahtar Kelimeler: Havaalanı, Hava Yolculuğu, Mobil Uygulamalar, Tedarik Zinciri, Değer Zinciri Analizi. 


\section{INTRODUCTION}

Air travel did grow over the last 27 years annually by $5.9 \%$ on average in terms of passenger-kilometer performed (PKP), and by $6.1 \%$ in terms of tonkilometer performed (TKP), [1]. With the increasing air traffic airlines are utilized above 10 hours per day reaching a load factors above $80 \%$ [2]. As a result the forecasted annual traffic growth is around $4.8 \%$ thru 2036 [3], surpassing 9 billion passengers annually by 2025 [4].

Despite the growth in aviation, the economic constrains narrowed down the profit margins in aviation. Consequently smart customization leading to advanced segmentation is driving innovative business models with the aid of new technologies on the airline side [5]. This resulted in the reengineering of the airport concept. With the privatizations of the airports, they have become major business centers offering commercial development [4]. Today's airports are multifunctional public spaces not only processing passenger movement, but offering spa centers, boutiques and restaurants [6]. The worldwide commercial revenue average is around 48\% [7], but e.g. Schiphol is an airport city generating $70 \%$ of its operating result is by non-aviation-related income benefiting from the experience economy [8]. This change in business focus and increased environmental sensitivity drive together the innovation at the airports [9], which also positively effects airport's marketing performance [10]. Moreover considering that the commoditization is pushing the price as the key buying criteria; companies need to differentiate in the offerings [11], which implies innovation as well.

When changes necessarily drive towards innovations [12], productive use of inputs via continual innovation is due to maintain competitiveness [13]. Moreover some companies see the innovation as the enabler of additional growth [14]. Airports do leverage local monopolies in the aviation value chain [5]. By delivering products and services together with the flight processing they compete with each other to become successful hubs, centralizing the intermediary stations of the connection flights. Airports are trying to satisfy airlines technically, but also travelers with smooth operations and with a wide range of commercial offerings that they can innovate in strategy and vision, leadership, culture, processes or work environment [14].

Innovation is about interaction of technology, market and organization, where competitive advantage can be generated in the ways in which product and service offerings are created and delivered [15]. This is enabling also quality time spend at the airport, which must be offered by successful airports [8]. As of today some airport related innovations are self-service check-in, electronic permanent bag tags, self-service passport control, millimeter-wave technology security scans [8], mobile passenger identification, off-airport bag drop [16], automated border control machines, personalized real-time information using RFID [17]. The trend in functional airport partitioning is from sharp to fuzzy, breaking down categories by pointing out to social trends and technology [18], where information technology (IT) is used as a business enabler [19]. As a result the innovation at the airport shall include state of the art communication media based on IT and thus shall response to the online community as well.

The air travelers are from a higher socio-economic group [20]. Controlling their own trip, today's they are part of the online community and want to experience increasing transparency, corporate responsibility and efficiency [8]. The new social media is delivering many new communication channels that most of the passenger are actively part of. With an increasing trend (see Figure 1), over $78 \%$ of the passengers traveled in 2013 with a smartphone that airports provide Internet mobile services and flight updates via Mobile [21]. Which means, when the air traveler is at the airport, he/she is online. Moreover there is a positive correlation between the time spent at the airport terminal and the level of expenditure [22, 23], but e.g. $40 \%$ of the Schiphol Airport's passengers transfer to a connecting flight and are in the Netherlands just for a few hours [8]. As a result the traveler's commercially available time at the airport is adjusted by scheduling of transit flights [6].

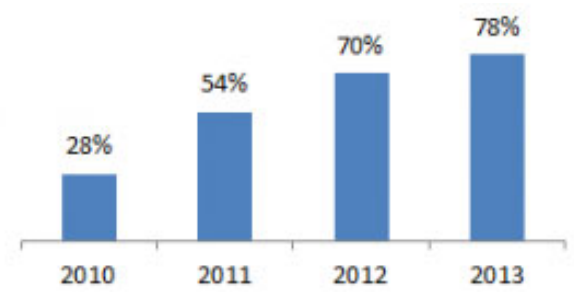

Figure 1. Smartphone penetration for air passengers based on $[24,25]$.

In addition to that considering the waiting times in front of check-in, passport and security control and baggage claim together with the time on the way to/from the airport, there is a huge amount of idle time, where the traveler is not within the value chain of the airport. Moreover the air traveler, who is mainly online, is virtually somewhere else that he/she is also mentally not integrated into the system as well.

However this idle time can be utilized by providing an online system incorporating the traveler as an active member into the airport community by providing information regarding the flight, but also offering commercial products and services such as duty-free, ground transportation, fast tracks or similar 
approaches, which is proposed here as the Gate $\varnothing$ system and explained in detail throughout the text.

There are already researchers focusing on the impact of the waiting time at the airports, but the utilization of this time is not covered in the literature, although it is critical to the perception of the service quality [26]. In addition to that this research also complements the literature of airport digital strategy, which is an important consideration currently lacking as well [27]. Finally the proposed Gate $\varnothing$ system is also assessed by applying a value chain analysis, contributing to the literature of the airport value chain as well.

\section{GATE Ø: THE AIR TRAVELER PORTAL}

Mobile check-in becoming bigger than web check-in indicates that passengers are ready for commercial mobile offerings as well [16]. Motivated with that, Gate Zero (Gate Ø) is the innovative software portal proposed herewith, which is leading the way to utilize the idle time of the air traveler into the value chain of the commercial airport cities. It is integrating the commercial offerings at the airports and enables the traveler an online access through smart mobile devices such as phones and pads, which can be used by the travels in their idle times (see Figure 2). In general it is a showcase of all the offerings available, but it is also a business platform and is an interactive communication channel suitable for marketing campaigns and for user evaluations.

The classical airport experience is associated to the physical airport, where a linear flow of processes is fallowed, i.e. for a departure flight after arrival by ground transportation, security check, check-in, baggage drop, passport control, last security check when due and there is just a short free time available prior departure.
This chain can diversify depending on the airport, but it is physically there. There are sometimes also innovative approaches using IT to crash some processes, but these processes always physically do happen, when even in a faster manner.

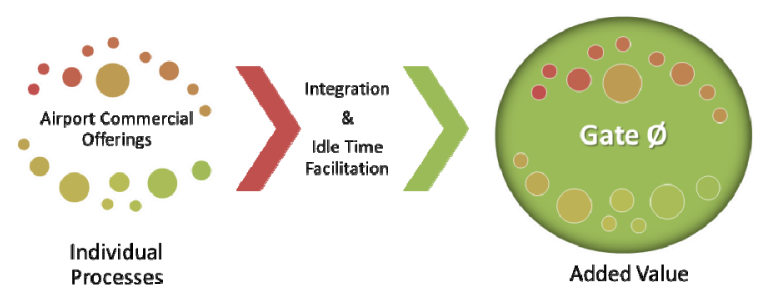

Figure 2. Gate $\varnothing$ as the integrator and commutator.

By using Gate $\varnothing$ first of all the airport will be virtually accessible at any time, meaning the traveler can prepare for a flight at home. Alternatively on the way to the airport, when stuck in the traffic, the time could be used to go for a fast track option combined with duty free as well. Since the system is also connecting to the commercial stakeholders, they can prepare a basket with procured goods and can get delivered at the gate in front of the aircraft. Marketing campaigns can be prepared and delivered to the customer, which can be accessed when visiting a city in the hotel or in a café downtown. Moreover the traveler can comment or read comments of other travelers, creating the content of Gate $\varnothing$ providing visibility, which is further supporting comparison possibilities of Gate $\varnothing$. As a result a traveler can access Gate $\varnothing$ when being at home, base in City X, or on the way to the Airport A, at Airport A, during the flight from Airport A to B, at arrival in $\mathrm{B}$ during immigration queue or baggage claim, during ground transport to City $\mathrm{Y}$ and in City $\mathrm{Y}$ (see Figure 3).

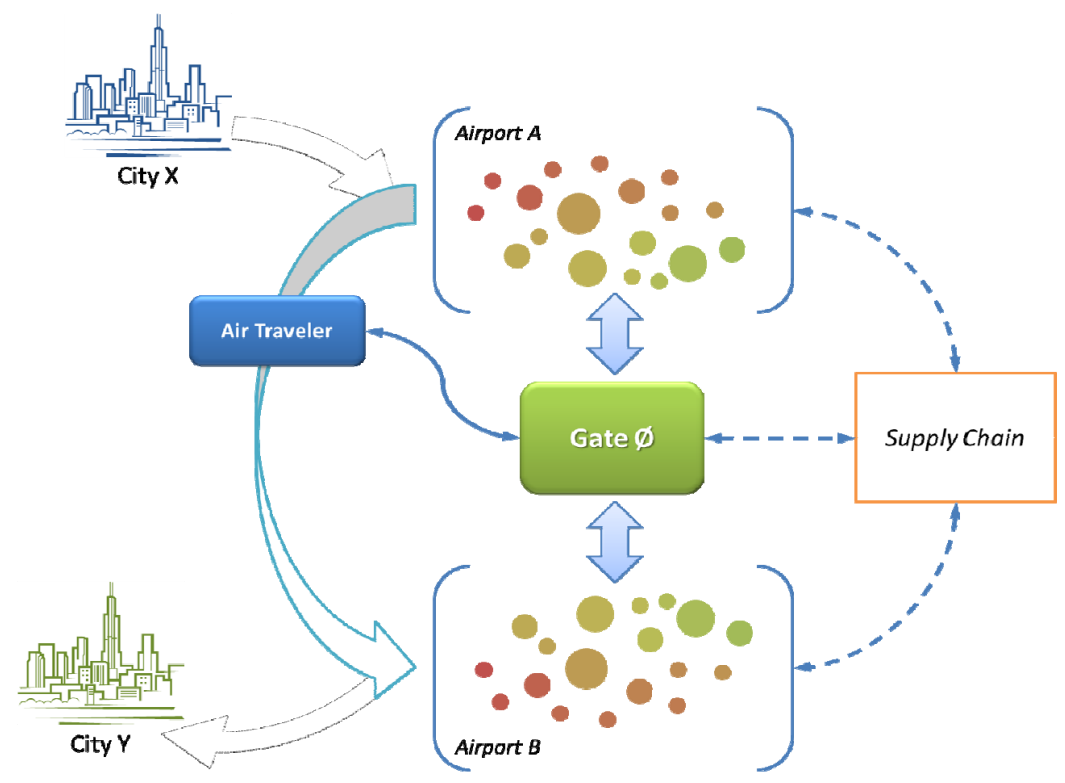

Figure 3. Positioning of Gate $\varnothing$ in the air travels commercial chain. 
During the initial implementation Gate $\varnothing$ can be used in a limited manner providing some additional capability only. Even this would mean for a smaller airport without the facilities a wide variety of offerings hence a radical improvement. When being used on the wide basis the stakeholders of Gate $\varnothing$ are (i) travelers, (ii) commercial service \& product providers directly along with (iii) airports indirectly.

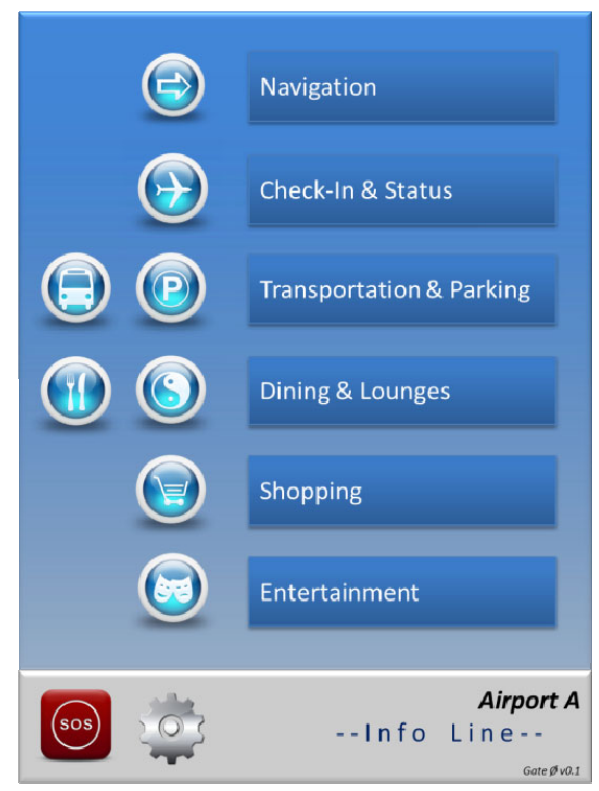

Figure 4. Mobile GUI structure of gate $\varnothing$.

When using the Gate $\varnothing$ the customer has a lean mobile graphical user interface (GUI) as shown in Figure 4. Since the system is using positioning services it can enable the navigation through the airport facilities. It uses interactive maps with destination selections from a searchable library including landmarks such as gates or administrative locations and commercial spaces as well. Under the Check-In \& Status branch all associated services and detailed information are available. Also fast tracks and the digital boarding card is included herein. With the Transportation and Parking branch the standard transportation means to and from the airport can be studied including time plans and procurement possibilities for packages of city public transportation cards together with offers of other commercial services available at the airport. Moreover daily, weekly or monthly subscriptions for the parking can be done where also the parking place is stored for later usage. Dining \& Lounges branch includes a presentation of available food court, lounge and airport hotel facilities including sleeping cubes, with the option to buy special combination packages. Shopping branch is mainly an e-commerce site, where visibility over product comparisons is provided. It includes all duty-free procurement options with several delivery options. Within the entertainment branch the associated facilities at or around the airport are promoted. Moreover movie channels are provided for a time based imbursement. The Info line includes streaming data according to the phase of the travel. Prior flight the time to boarding and departure info such as delays, gate number and flight number are shown in this line. After arrival the baggage claim belt number associated to the flight is indicated here, followed by the car park position when available. Also important information and advertisement are streaming here on a lower frequency. An alerting and communication system with pup-ups is available as well, where advertisements can be turned off in the settings branch, iconized at the lower part together with the SOS button. The SOS functionality is informing the authorities with the coordinates of the mobile device in the case of an emergency, where massages indicating the situation can be send as well. Finally it has to be mentioned that the commercial users have a sophisticated desktop GUI enabling them e-commerce transactions and other functionalities, which is not shown here.

\section{METHOD: VALUE CHAIN ANALYSIS}

In order to assess Gate $\varnothing$, value chain analysis is used. "The value chain is a general framework for thinking strategically about direct, indirect or quality activities involved in any business assessing their relative cost and role in differentiation, since the competitive advantage cannot be seen by looking at a firm as a whole" [28]. Consequently all stakeholders of Gate $\varnothing$ are to be analyzed within the value chain including the suppliers, the commercial service \& product suppliers at the airport, the travelers and at least the airport itself.

Due to the lack of the ability to fully conceptualize the complex adaptive nature of service innovation and value [19] the assessment of Gate $\varnothing$ is not an easy mathematical computational task. Traditional value chain analysis is very structured and uses isolated processes and appropriate costs and incomes. According to [29] the principal steps are first identifying the firm's value-creating processes to determine the portion of the total cost of the product or service attributable to each value creating process, which can be used to identify the cost drivers for each process and to identify the links between processes. However IT innovations enable a user value, which cannot be measured by traditional accounting and economic based measuring techniques [19], where the customer contribution is further boosting the value. Moreover operational performance is measured against non-financial value drivers such as operational efficiency, service quality, environmental responsibility and corporate sustainability [19]. Consequently a more qualitative approach is used herewith for the primary and support activities based on the generic value chain [28] as shown in Figure 5. 


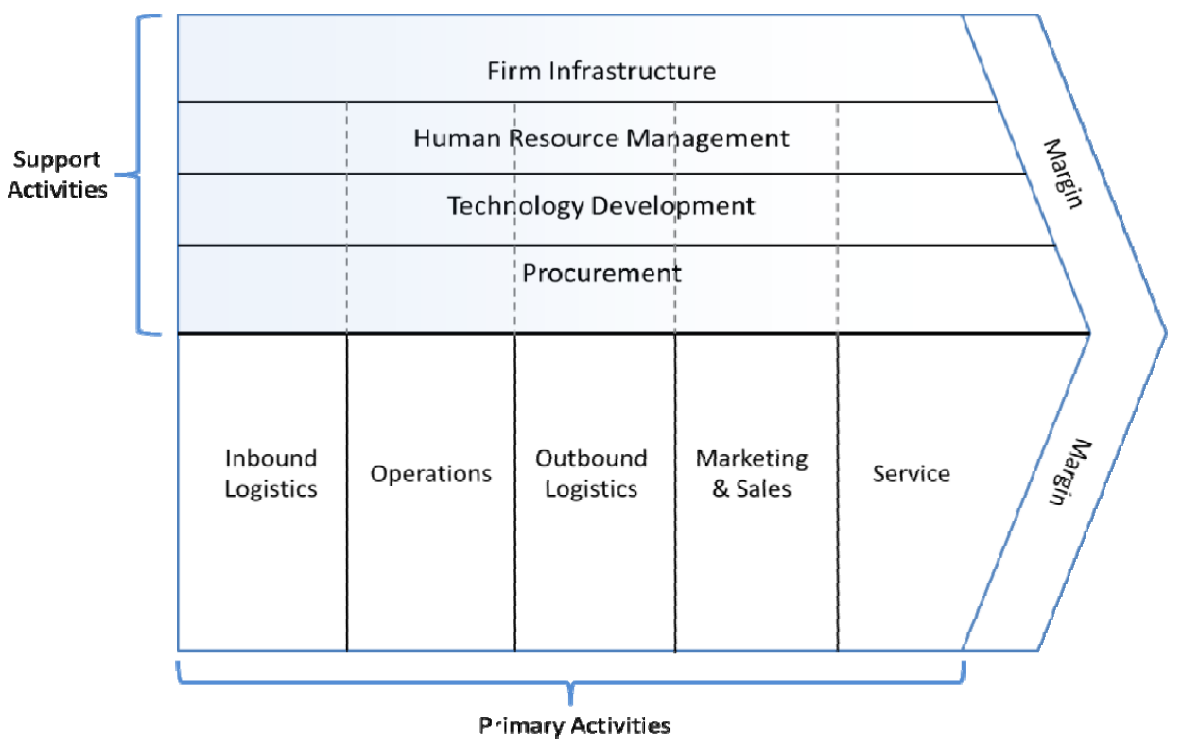

Figure 5. The generic value chain based on [28].

The qualitative value chain analysis of Gate $\varnothing$ is summarized in Picture 6. The infrastructure delivers a customer focused system enabling the collaboration across all stakeholders including the streaming of the voice of the customer (VOC). It is a superior management information system (MIS), integrating sales \& marketing with the tracking of key performance indicators (KPIs) enabling financial reporting as well. Successively it is a top management support tool including but not limited to selling strategy. The infrastructure is delivering an electronic data interchange (EDI) environment, enabling computer to computer exchange of business documents preventing manual interaction limiting error sources and streamlining all processes. Moreover it provides a great overview of the current as-is situation by delivering transparency to the customer leading to a higher image perception.

For inbound logistics processes Gate $\varnothing$ is capable to be used as a web based training resource with the provided online catalogue. With shared resources as a main character, Gate $\varnothing$ can facilitate online support on all primary activities reducing the need of human resources (HR). The automated processes require a lower work force and increase the quality of work together with the efficiency. On the top of this Gate $\varnothing$ is not only a customer focused system, the customer acts in Gate $\varnothing$ as the content provider, i.e. it is generating content within the processes. This implies that the customer is as well functioning as an associate in the self-organizing concept. He/she uses the information on the system, realizes his own transactions, but guides also other participants. By taking over some of the load from the sales force the customer also supports the organization to get leaner, enabling free resources which then can be converted to higher skilled back office personnel, who can increase the level of value and quality. Moreover Gate $\varnothing$ is integrating the supplier into the value chain on a collaborative basis that some outbound duties of the stores can be taken over from the suppliers such as delivery or inventory, which again mitigates the requirement on HR. On the top of this the shared resources on several locations provide a much better coverage on global basis and deliver a higher level of visibility.

As an innovative platform Gate $\varnothing$ has its main contributions on the technology development activities. Being an automated business to business (B2B) system it enables the smooth information exchange between the suppliers and the companies. As a result the inbound logistics is made on a fault free basis in shortest time possible. There are several services of the airports available in Gate $\varnothing$ in an integrated context, which is $7 / 24$ available to access. The lean system is providing a robust IT platform and since most of the transactions are carried in virtual reality the need of physical department store space at airports decreases. The bidirectional information flow is contributing to the transparency. The idle time integration into the value chain is one of the main assets of Gate $\varnothing$. The traveler, here the customer, is virtually present at all times and can follow up the content provided to fulfill even transactions, where the required support can be provided in an online manner. Moreover the service/product providers can use shared resources to fulfill the requirements of the orders. E.g. while a store in Airport A is passing by the delivery of one selected item which is not currently available to another store at Airport B, it can still give out beverages locally. Many similar tailored business models can be worked out to maximize the profit of all contributing parties. 




Figure 6. The value chain analysis for gate $\varnothing$.

Being a customer to business (C2B) system it is also an integrated system enabling just in time (JIT) logistics with wide spectra of delivery options. The customer therefore can choose to pick-up the goods on a designated site for cost cutting or can prefer to have an in-house delivery against a small reimbursement fee. All in one the inventory management captured by Gate $\varnothing$ provides a good visibility and enables smoother transactions. Providing a higher awareness level to the online community and streaming information over mobile devices a higher advertisement level can be achieved by Gate $\varnothing$. Moreover the availability period is extended by two means; (i) the shared resources enabling physical access and (ii) the virtual environment providing access making the ecosystem available over a longer period without time lapses.

Qualitative VOC together with the quantitative metrics extracted from Gate $\varnothing$ can be used to conduct extensive market research making successful promotions possible. Moreover with subscriptions with longer term commitments special offers can be arranged to increase total profit. Moreover there are practically no physical restrictions anymore. Theoretically any product can be included virtually in the offerings enabling a diversification of product lines as well. Special pricing and packaging promotions can be carried out within innovative corners at stores with another core business than retail, which also enables cross selling. Since the customer is benefiting from the experience economy the value differentiation can be achieved as shown in Figure 7, where the positive perceived value is raised by the application of Gate $\varnothing$ and the negative actual input cost, the actual value, is decreased due to the optimization of processes. Consequently the difference between perceived and actual values of $\mathrm{A}$ and $\mathrm{B}$ respectively can be used to determine the differentiation value. Moreover the customer has more time to process the transactions by using e-payment. This relaxes the customer and he/she can decide to go for expensive products from elevated segments. All together a new high end customer segment can be created, which can be served by means of account management.

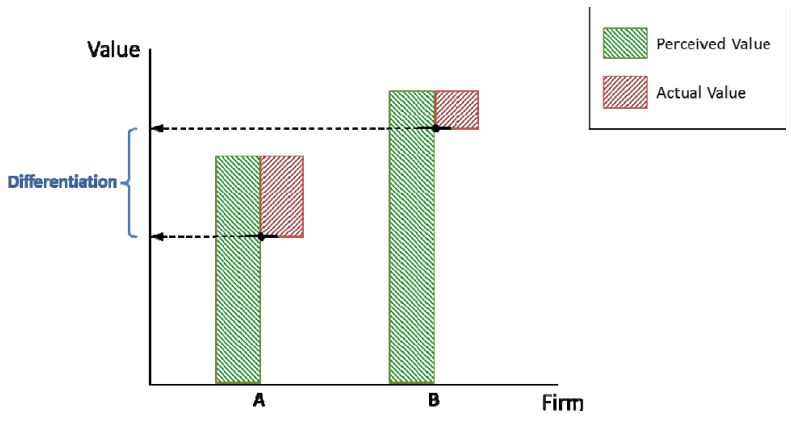

Figure 7. Value differentiation. 
All in one the JIT procurement with possible delivery options enables a positive environment aspect as well. All goods flown directly with the customer do require a higher amount of fuel consumption due to air transportation. Each $\mathrm{kg}$ carried on board is used to calculate the total fuel boarded. In other terms when the customer choses to have delivery at destination it is not just a comfort choice done in order to prevent carrying around the goods, it also results in a lower carbon foot print. Thus shared inventory has a green aspect as well.

In addition to that the reverse logistics concept, which starts with the procurement of the customer and immediately escalades the information down to the suppliers, is also reducing the unnecessary inventory, lowering space requirements and thus electricity and other overheads financially and environmentally. Joint procurement enables also the selection of most suitable goods to create services. Finally the best located warehouses holding the inventory in the name of duty free shops can be selected to provide the goods on the greenest pathway. As a result interrelationships in joint procurement cover joint interface of Gate $\varnothing$, shared financing of the inventory, order processing, advertisement and promotion.

\section{RESULTS AND DISCUSSION}

The findings of the value chain analysis are consistent with the expectance. By breaking down the processes and focusing on subsystem level it has been found that Gate $\varnothing$ integrates the idle time of the air traveler into the value chain of the airport.

Focusing on the sustainability criteria for airports as economic efficiency, environment, coordination, and community [4], it has been shown that Gate $\varnothing$ delivers a suitable platform by providing an integrated collaborative approach involving the JIT, VOC integration and transparency. Especially the new social community wants to be involved in processes, which is satisfied herewith, supported by this transparency referred and the bidirectional information flow. It has been shown that Gate $\varnothing$ is enabling the required differentiation [28] for sustainable success by reducing the power of price with the perceived value increase due to the IT and participation to the content. Considering that consumers are increasingly aware of social and ecological consequences [30], the indicated green character of Gate $\varnothing$ cutting down fuel consumption by optimized logistics contributes to the sustainability of both the ecosystem and the business model incorporating Gate $\varnothing$.

Moreover Gate $\varnothing$ implies technological innovation by the adaptation of the mobile platform applications integrating the supply chain of several locations. Cooperation possibilities as indicated in the value chain analysis seek the benefits of centralization and economies of scale shifting a large part of planning and administrative tasks to the central unit, which will save time and resources in stores, increasing negotiation power [30]. In addition to that Gate $\varnothing$ drives a process innovation from the perspective of the commercial stakeholders. It has been shown that supply chain is totally reengineered by using state of the art ecommerce platform enabling inventory optimization along with several new delivery options. The traveler gets part of the process at all physical locations possible, that idle time utilization has been proven to be correct. The integrated approach also implies paradigm innovation, since it changes the underlying mental model [15] associated to the experience at the airport.

Considering that at airports marketing innovation is found in service companies [10], where the product is simultaneously produced with and consumed by participating customers [11], one can question the positioning of Gate $\varnothing$ therefore. Since Gate $\varnothing$ is integrating the customer into the processes it is addressing the required needs as content created by customers. Furthermore communication of special combined offerings such as lounges together with fast tracks or with duty free shopping implies the marketing character of Gate $\varnothing$.

On the top of this, todays airports are like big cities, which are competing with each other. The more they attract people by delivering them a pleasant traveling experience the more the airlines prefer the airports as hubs or home bases. Since Gate $\varnothing$ is elaborating the travel experience it is also indirectly contributing to the marketing of the airport. Moreover airports have also revenue generating units such as parking, which integration into Gate $\varnothing$ would make airports direct stakeholders of the system as well. As a result by limited application Gate $\varnothing$ can be impact incremental innovation contributing to sales and marketing, but has been shown that it is a radical innovation for airports, not possessing any comparable duty free zone prior implementation. Since in-store technology facilitating purchasing via mobile phone platforms easily gives benefits to retailers and suppliers [30], competitive positioning of Gate $\varnothing$ adopters is enhanced. The underlined corner logic is in line with shop-in-shop concepts and the fuzzification of food and non-food areas [30].

Furthermore enabling further optimization in the organization it also delivers higher efficiency in HR contributing to the reduction of costs. Together with the new optimized logistics and reduced inventory as shown by the analysis, the cost impact is even higher. This contributes to the referred differentiation, which together with the new business opportunities justified the Gate $\varnothing$ application. 


\section{CONCLUSIONS}

Despite the growth in air traffic the profit margins of aviation is lowered due to competitive positioning of alternative airports, trying to attract airlines with competitive aeronautical fees. Consequently airports are restructuring themselves from operators only towards participants of the experience economy encompassing commercial offerings for air travelers to sustain their profitability. The utilization of commercial spaces in airports is not only restricted to retail and food courts, but airport cities with a sociocultural environment are developing. The air traveler profile on the other side is also changing. Today most of the travelers are member of the online community and like to accelerate processes by using mobile technologies. However the increasing loads of airports make waiting lines inevitable. Consequently the travelers are virtually somewhere else including but not limited to these moments at the waiting lines and this embodies an idle time of the air traveler when the traveler is not within the value chain of the airports. On the top of this the unpleasant experience of waiting reduces the motivation of the travelers for spending any money. All together the commercial spaces of the airports and consequently the airports do lose money.

In order to overcome this problem an innovative customer focused integrated platform called Gate $\varnothing$ is proposed and developed. This smart phone platform, facilitating the idle times of the air traveler, as well integrating the commercial stakeholders has been further evaluated by using a value chain analysis. It has been shown that added value has been delivered by integrating the traveler into the processes. Moreover joint operations of several commercial stakeholders have been proven to be beneficial in terms of efficiency but also providing new sales possibilities. It has been shown that using Gate $\varnothing$ the traveler can be virtually part of the experience economy of the airport, when in waiting lines or when even being physically somewhere else. The idle time facilitation was proven therefore, integrating the traveler into the value chain of the airport commercial ecosystem, which was shown to be beneficial over long time for the airport management as well.

All in one it has been shown that Gate $\varnothing$ has innovative impacts in many dimensions including technological, process, marketing and paradigm innovation, which delivered together with the efficiency improvements by the Gate $\varnothing$ application the basis to sustainable success.

\section{REFERENCES}

[1] Mazraati, M., (2010) "World Aviation Fuel Demand Outlook", OPEC Energy Review, Vol. 34, Issue 1, pp. 42-72.
[2] Harned, D.S., Sheehy, F., Cofsky, J., (2007) "Commercial Aircraft Cycle: Party Like It's 1999?" White Book, Bernstein Research.

[3] ICAO, (2010) "Present and Future Aircraft Noise and Emissions Trends", Assembly, International Civil Aviation Organization - 37th Session, Agenda Item 17: Environmental protection, A37-WP/26 EX/9 21/7/10.

[4] Stevens, N.J., Baker, D.C. \& Freestone, R., (2010) "Airports in their urban settings: towards a conceptual model of interfaces in the Australian context". Journal of Transport Geography, 18(2), pp. 276-284.

[5] Franke, M., (2007) "Innovation: The winning formula to regain profitability in aviation?" Journal of Air Transport Management, 13, pp. 23-30.

[6] Nikolaeva, A., (2012) "Designing Public Space for Mobility: Contestation, Negotiation and Experiment at Amsterdam Airport Schiphol". Tijdschrift voor Economische en Sociale Geografie, Vol. 103, No. 5, pp. 542-554.

[7] ACI, (2012) “Commercial Revenues' Resilience Key to Airport Investment \& Modernization". ACI: Airports Council International, Press Release, http://www.atn.aero/article.pl?id=36324.

[8] Nijhuis, J.A., (2012) "Creating the i-Port: Innovative strategies to enhance efficiencies and the passenger experience". Airport Management, Vol. 7, No. 1, pp. 8-12.

[9] Humphreys, I. \& Francis, G., (2002) "Performance measurement: a review of airports". International Journal of Transport Management, 1, pp. 79-85.

[10] Halpern, N., (2010) "Marketing innovation: Sources, capabilities and consequences at airports in Europe's peripheral areas". Journal of Air Transport Management, 16, pp. 52-58.

[11] Rothkopf, M. \& Wald, A., (2011) "Innovation in Commoditized Services: A Study in the Passenger Airline Industry". International Journal of Innovation Management, Vol. 15, No. 4, pp. 731-753.

[12] Iyer, R.; Laplaca, P.J.; Sharma, A., (2006) "Innovation and New Product Introductions in Emerging Markets: Strategic Recommendations for the Indian market". Industrial Marketing Management, 35, pp. 373-382.

[13] Porter, M.E., (1998a) "Clusters and the New Economics of Competition". Harvard Business Review, Vol. 76 Issue 6, pp. 77-90.

[14] Stamm, B., (2003) "The Innovation Wave: Meeting the Corporate Challenge". Wiley \& Sons Ltd.

[15] Tidd, J., Bessant, J \& Pavitt, K, (2005) "Managing Innovation: Integrating Technological, 
Market and Organizational Change". 3rd Edition, John Wiley \& Sons, Ltd.

[16] Léopold, E., (2009) "The future of mobile check-in". Airport Management, Vol. 3, No. 3, pp. 215-222.

[17] Noronen-Juhola, H., (2012) "Smart solutions at Helsinki Airport”. Airport Management, Vol. 6, No. 2, pp. 125-132.

[18] Matthews, L., (2000) "Airports of the Future: A Manager's View of an Innovation Exercise". International Journal of Innovation Management, Vol. 4, No. 2, Special Issue, pp. 187-205.

[19] Granta, K., Alefantos, T., Meyer, M. \& Edgar D., (2013) "Capturing and measuring technology based service innovation - A case analysis within theory and practice". International Journal of Information Management, 33, pp. 899-905.

[20] Graham, A., (2009) "How important are commercial revenues to today's airports?" Journal of Air Transport Management, 15, pp. 106-111.

[21] SITA, (2014a) "Airport IT Trends, Survey 2014". Société Internationale de Télécommunications Aéronautiques, http://www.sita.aero/surveysreports/industry-surveys-reports/airport-it-trendssurvey-2014 .

[22] Torres, E., Dominguez, J.S., Valdes, L. \& Aza, R., (2005) "Passenger Waiting Time in an Airport and Expenditure Carried out in the Commercial Area". Journal of Air Transport Management, 11 (6), pp. 363-67.

[23] Castillo-Manzano, J.I., (2010) "Determinants of Commercial Revenues at Airports: Lessons Learned from Spanish Regional Airports". Tourism Management, 31 (6), pp. 788-96.

[24] SITA, (2013) "Passenger Self-Service Survey 2012". Société Internationale de Télécommunications Aéronautiques, http://www.sita.aero/surveysreports/industry-surveys-reports/passenger-selfservice-survey-2012.

[25] SITA, (2014b) "Airport IT Trends Survey 2013”. Société Internationale de Télécommunications Aéronautiques, http://www.sita.aero/surveysreports/industry-surveys-reports/airport-it-trendssurvey-2013.

[26] Fodness, D., \& Murray, B., (2007) "Passengers' expectations of airport service quality". Journal of Services Marketing, 21 (7), pp. 492-506.

[27] Jaffer, S. \& Timbrell, G., (2014) "Digital Strategy in Airports". 25th Australasian Conference on Information Systems, 8-10 ${ }^{\text {th }}$ Dec 2014, Auckland, New Zealand.

[28] Porter, M.E., (1998b) "Competitive Advantage: Creating and Sustaining Superior Performance, with a new Introduction". The Free Press.

[29] IMA, (1996) "Value Chain Analysis for Assessing Competitive Advantage". Institute of Management Accountants (IMA), Montvale.

[30] Finne, S. \& Sivonen, H., (2009) “The Retail Value Chain: How to gain competitive advantage through Efficient Consumer Response (ECR) Strategies". Kogan Page.

\section{VITAE}

\section{Dr. Caglar UCLER}

Dr. Ucler has graduated the Technical University of Munich (TUM) as a "Diplom Ingenieur" in Mechanical \& Aerospace Engineering and finished his $\mathrm{PhD}$ in Concurrent Engineering at Marmara University.

He worked in several industrial projects, where he focused on simulation, $R \& D$ and technology management. He was the former Deputy General Manager of FIGES, serving mainly aerospace \& defense and automotive industries. He worked in Aritas as the Engineering Director and as the founding manager of the German Branch.

He is currently faculty member in the School of Aviation at Ozyegin University and is also consultant for Worthington Aritas. He focuses mainly on product development and its management.

\section{Luis MARTIN-DOMINGO, MSc.}

Luis Martín-Domingo received a BSc Aeronautical Engineering (1994) at Universidad Politecnica de Madrid (Spain) and later an MSc Air Transport Management (1998) at Cranfield University (UK).

He has more than 10 years of experience in the areas of Marketing and Distribution of airlines and airports in Europe and China. Before joining Özyeğin University he lectured at Eseune Business School in Beijing (China) and is visiting lecturer at Paul Sabatier University in Toulouse (France).

Now in Istanbul he combines his Air Transport lectures at Özyeğin University with his $\mathrm{PhD}$ at Las Palmas University (Spain) where he research on the use of mobile internet services at airports. 